\title{
VCO (Virgin Coconut Oil) PEJATI DARI LIMBAH BUAH KELAPA PERSEMBAHAN BANTEN MANTAPKAN EKONOMI TUKANG SAPU DI AREAL PURA PENATARAN DALEM PED, NUSA PENIDA
}

\author{
I Ketut Andika Pradnyana \\ Jurusan Teknologi Pembelajaran, Universitas Pendidikan Ganesha \\ e-mail: andika.pradnyana@undiksha.ac.id
}

\begin{abstract}
Abstrak
Pura Penataran Dalem Ped merupakan salah satu pura Kahyangan yang ada di Nusa Penida. Berdasarkan hasil wawancara dengan salah satu tukang sapu di pura ini, jumlah pemedek (pengunjung yang melakukan persembahyangan) pada hari biasa mencapai 100 orang per hari, hari sabtu dan minggu mencapai 800 orang, dan pada hari tertentu seperti purnama dan odalan pura mencapai 5.000 lebih pengunjung sehingga menghasilkan limbah kelapa yang banyak. Oleh karena itu membutuhkan sosialisasi kepada masyarakat cara pengolahan kelapa menjadi VCO. Tujuan kegiatan ini adalah untuk meningkatkan penghasilan mitra yakni Tukang sapu di Pura Penataran Dalem Ped. Metode yang digunakan adalah penyuluhan dan praktek mengolah diversifikasi produk berbahan dasar kelapa. Hasil yang diperoleh adalah mitra mampu memproduksi VCO secara mandiri, mitra memiliki pengetahuan tentang mengolah limbah kelapa yang dapat dimanfaatkan untuk membuat VCO, meningkatkan pendapatan dan adanya memasarkan produknya di Nusa Penida sebagai produk khas oleh - oleh.
\end{abstract}

Kata kunci: VCO, Pura Penataran Dalem Ped, Nusa Penida, Tukang Sapu, Kelapa Pejati

\begin{abstract}
Penataran Dalem Ped temple is one of the heavenly temples in Nusa Penida. Based on the results of an interview with one of the sweepers in this temple, the number of pemedek (visitors who make prayers) on normal days reaches 100 people per day, Saturdays and Sundays can reach 800 people, and on certain days such as full moon and temple temple reaches 5,000 more visitors so as to produce a lot of coconut waste. Therefore it requires socialization to the community on how to process coconut into VCO. The purpose of this activity is to increase the support of partners namely sweepers at Penataran Temple Dalem Ped. The method used is counseling and practice processing coconut-based product diversification. The results obtained are partners who can produce VCO independently, partners who have knowledge of coconut processing that can be used to make VCO. After this service was carried out, the partners began to realize the importance of agricultural products to increase revenue and market their products in Nusa Penida as a typical souvenir product.
\end{abstract}

Keywords : VCO, Pura Penataran Dalem Ped, Nusa Penida, Tukang Sapu, Kelapa Pejati 


\section{PENDAHULUAN}

Pulau Nusa Penida merupakan bagian dari wilayah Kabupaten Klungkung dan termasuk dalam kecamatan Nusa Penida. Pulau ini terletak di selatan dari kota Semarapura dengan menggunakan sarana penyeberangan. Penyeberangan yang bisa dilakukan yaitu melalui Pelabuhan Padang Bai dengan kapal feri dan speed boat, Pelabuhan Kusamba dan Tribuana dengan speed boat. Pulau Nusa Penida memiliki luas $\pm 414 \mathrm{~km}$. Pulau Nusa Penida sekarang ini sedang dikembangkan menjadi "The Blue Paradise Islands" semenjak diadakannya Nusa Penida Festival 2016 pada tanggal 7 - 9 Oktober 2016. Hal ini sangat didukung oleh adanya potensi wisata yang ada di Nusa Penida.

Potensi wisata yang dikembangkan di Nusa Penida meliputi wisata bahari, touring, dan wisata spiritual. Wisata bahari di pulau ini sangat diminati apalagi dengan adanya ikan langka dan unik yaitu molamola. Keindahan terumbu karang di perairan laut ini juga sangat indah. Keindahan ini menjadi magnet daya tarik wisata yang luar biasa bagi wisatawan. Nusa Penida juga memiliki keindahan alam yang sangat unik, seperti pantai Atuh, Crystal Bay, Guyangan, Temeling, Manta Point, Nyuh Beach, Bukit Teletubies, dan keindahan alam lainnya. Banyaknya objek wisata ini menjadi salah satu potensi touring wisata. Selain keindahan alam, pulau ini juga memiliki potensi wisata spiritual. Hal ini karena banyaknya purapura di Nusa Penida yang unik dan dipercaya memiliki kekuatan "Taksu Bali". Salah satunya adalah Pura Penataran Dalem Ped.

Pura Penataran Dalem Ped merupakan salah satu pura Kahyangan yang ada di Nusa Penida. Berdasarkan hasil wawancara dengan salah satu tukang sapu di pura ini, jumlah pemedek (pengunjung yang melakukan persembahyangan) pada hari biasa mencapai 100 orang per hari, hari sabtu dan minggu bisa mencapai 800 orang, dan pada hari tertentu seperti purnama dan odalan pura mencapai 5.000 lebih pengunjung. Tujuan orang melakukan persembahyangan di pura ini yaitu untuk memohon keselamatan, kesejahteraan, dan ketenangan kepada Tuhan, dan sebagai bentuk rasa syukur dan persembahan kepada Tuhan. Pemedek yang akan melakukan persembahyangan biasanya membawa persembahan banten pejati. Banten ini adalah bentuk persembahan yang dipakai sarana untuk menyatakan rasa kesungguhan hati kehadapan Hyang Widhi dan manifestasiNya, akan melaksanakan suatu upacara dan mohon dipersaksikan dengan tujuan agar mendapatkan keselamatan. Salah satu bentuk persembahan yang ada di dalam banten ini adalah buah kelapa.

Menurut penuturan dari salah satu tukang sapu (Nengah Erdiawan), Banten Pejati berupa kelapa dari pemedek biasanya ditempatkan di pura. Pada hari biasa, buah kelapa yang dikumpulkan mencapai 100 butir per hari, sedangkan pada hari raya besar mencapai 600 per hari.

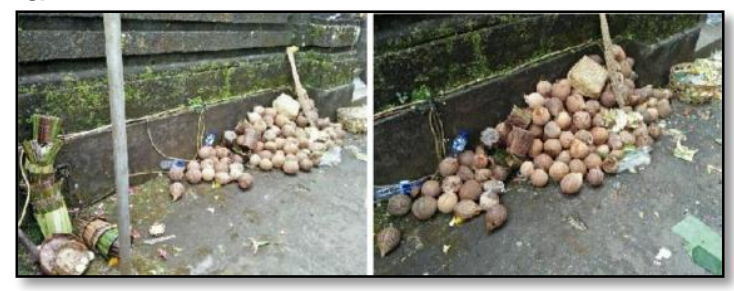

Gambar 1. Limbah buah kelapa dari banten pejati

Kelapa-kelapa tersebut di dikumpulkan oleh tukang sapu untuk dijadikan pakan ternak dan minyak goreng. Tukang sapu yang ada di pura berjumlah 30 orang yang bekerja dengan sistem shift dan kontrak selama 2 tahun. Gaji yang mereka dapatkan sekitar 1.300.000 per bulan. Selama dalam kontrak mereka berdiam di pura dan jarang ke rumah masing-masing, kecuali memberikan nafkah istri dan keluarga serta jika ada acara adat. Penghasilan yang demikian dirasa masih kurang oleh tukang sapu, sehingga mereka mencoba mengolah kelapa yang diperoleh menjadi minyak goreng dan sebagian dijual. Pengolahan buah kelapa menjadi minyak goreng membutuhkan waktu yang lama dan sarana yang lumayan banyak, seperti prosesnya yang lebih lama dan kebutuhan akan kayu bakar yang jumlahnya semakin terbatas. 
Sehingga ini akan memberikan pengaruh keinginan tukang sapu mengolahnya semakin berkurang dan tentu biayanya akan lebih tinggi. Di samping itu minyak goreng dari buah kelapa bersaing harganya dengan bahan kelapa sawit yang lebih murah.

Para tukang sapu sebenarnya ingin meningkatkan pendapatan dengan memanfaatkan peluang dan potensi pura yang ramai dikunjungi pemedek. Mereka ingin mengubah limbah kelapa yang berlimpah menjadi sesuatu yang lebih bernilai guna yaitu mengolahnya menjadi VCO(Virgin Coconut Oil). Pilihan akan pengolahan limbah buah kelapa dari banten pejati menjadi VCO sangat beralasan. Minyak kelapa murni yang sering dikenal dengan minyak perawan, minyak dara atau Virgin Coconut Oil (VCO) sangat bermanfaat untuk kesehatan. Tren masyarakat saat ini yang kembali pada pola makanan untuk kesehatan dari alam semakin membuat VCO banyak digemari. Kegunaan dari VCO antara lain mengurangi lemak yang ada pada tubuh, menangkal radikal bebas, menurunkan kadar kolesterol, sebagai cadangan antioksidan dalam tubuh, menurunkan resiko terjadinya penyakit jantung dan kanker (Widiyanti, 2015). VCO juga baik untuk kesehatan kulit dan rambut seperti menjaga kelembapan kulit, meningkatkan elastisitas kulit, mencegah pembentukan strech marks, dan merawat rambut. Manfaat yang banyak dari VCO akan memudahkan pemasaran penjualan dari produk yang dihasilkan berbasis VCO, sehingga nantinya dapat dibuatkan stand VCO di areal pura dan juga dipasarkan ke luar Nusa Penida. Dengan adanya stand produk VCO dari bahan limbah buah kelapa banten pejati, maka ini akan menjadi salah satu oleh-oleh khas Nusa Penida yang bermanfaat untuk kesehatan. Banyaknya manfaat yang ada pada VCO memnjadikan minyak ini menjadi peluang usaha yang dapat dijdikan solusi untuk menambah ekonomi keluarga (Raras, 2016). Dapat kita bayangkan jika setiap hari VCO yang dihasilkan dapat dipasarkan kepada pemedek, tentu ini akan meningkatkan pendapatan tukang sapu.
Berdasarkan hal tersebut, maka ketua tukang sapu (Nengah Erdiawan) mengharapkan adanya pelatihan kepada para tukang sapu tentang cara pengolahan VCO menjadi produk ekonomis dengan diversifikasinya seperti parfum VCO.

Minyak kelapa murni atau biasa disebut VCO (singkatan dari Virgin Coconut Oi) yang telah terbukti bermanfaat bagi kesehatan, saat ini mulai banyak dicari orang untuk menyelesaikan permasalahan kesehatan. Produk VCO menjadi makin dicari konsumen karena VCO mempunyai khasiat yang baik terhadap kesehatan antara lain dapat menurunkan berat badan sebagai diet VCO (Hadibroto dan Srikandi, 2006), sebagai anti oksidan, anti virus, anti protozoa dan anti bakteri (Wibowo, 2006; Ruku. 2007). Konsumsi VCO sangat baik untuk memperbaiki sistem saluran pencernaan, melancarkan buang air besar, dan mengobati diare (Iskandar, 2006). Hal ini juga didukung oleh adanya tren produk "kembali ke alam" atau "go organik" yaitu menggunakan produk yang berasal dari bahan-bahan alam dan murni. Selain itu juga, adanya masyarakat yang mempunyai ketergantungan tinggi terhadap obat-obat kimia dan merasa tidak ada perubahan semakin meningkatkan kebutuhan akan minyak murni ini sebagai obat.

\section{METODE}

Metode yang digunakan dalam program kreativitas mahasiswa ini yaitu metode kerja kolaborasi antara penulis dengan Tukang Sapu.

1. Metode Observasi dan Wawancara

Observasi dan wawancara dilakukan pada hasil kegiatan pelatihan. Observasi lokasi pemasaran juga dilakukan. Wawancara mengenai kemampuan tukang sapu dan minatnya untuk mengembangkan produk VCO sebagai produk oleh-oleh menjadi suatu bentuk informasi keberhasilan dari pelatihan ini.

2. Metode Pelatihan dan proses produksi

Penyuluhan dan pelatihan diikuti oleh 30 Tukang Sapu yang bekerja di Pura Dalem Ped. Pelatihan pembuatan VCO dilakukan dengan dua cara yang sederhana yaitu pengadukan dan pengadukanpancingan (lampiran brosur). Pada 
pelatihan ini akan diberikan penyuluhan cara pembuatan, sumber kelapa, kesehatan kerja, manfaat VCO, dan teknis-teknis yang berkaitan dengan pembuatan VCO.

a) Tahap Pelatihan

Pelatihan dilakukan bulan Desember 2019 yaitu dari tahap persiapan, pelatihan, proses produksi, pengemasan, pemasaran dan evaluasi,. Pada tahap persiapan dilakukan koordinasi waktu pelatihan, penyiapan alat dan bahan, penyiapan kemasan, brosur dan pamplet. Kegiatan pelatihan dilakukan selama 7 kali. Pada kegiatan ini dibagi menjadi beberapa kelompok dan dilatihkan dari proses pemilihan bahan kelapa pejati yang baik digunakan, pembuatan santan, pemisahan kanil, pengadukan dan penambahan pancingan VCO, pemisahan VCO dari blondo, penyaringan, pengemasan menjadi dua produk (original dan aromaterapi), hingga pemasaran produk. Hasil pelatihan ini memberikan dampak yang baik untuk penghasilan para tukang sapu, karena setiap minggunya setiap orang mampu membuat 2-5 liter VCO yang dilakukan di sela-sela bekerja sebagai tukang sapu. Setiap liternya seharga Rp.70.000, dan jika dikemas dalam botol lebih kecil, maka setiap liternya bisa mencapai keuntungan Rp. 100.000 .

\section{b) Proses Pembuatan VCO}

1) Bahan dan Alat

Bahan : Kelapa, alkohol 70\%, VCO pancingan, kapas dan kertas saring. Peralatan : Sprayer alkohol, tisu / lap bersih untuk sterilisasi peralatan; Alat pemarut kelapa; ember besar, baskom kecil dan besar; pengaduk / mixer, sendok panjang; selang untuk memisahkan santan kanil dan encerannya, dan untuk memisahkan minyak, blondo dan VCO; botol pengemasan; corong besar dan kecil; dan saringan .

\section{2) Proses Pembuatan VCO}

Proses pembuatan VCO dilakukan dengan duacara yaitu cara pengadukan, dan pengadukan pancingan. Teknik pengadukan - pancingan memberikan hasil minyak VCO yang lebih banyak daripada metode pengadukan saja. Metode pengadukan hanya menghasilkan $500 \mathrm{~mL}$ untuk 10 butir, sedangkan metode pengadukan-pancingan menghasilkan 800 $\mathrm{mL} / 10$ butir kelapa pejati. Prosedur pembuatan dibuatkan dalam bentuk brosur. Selain pelatihan pembuatan VCO, juga disampaikan pemanfaatan limbah dari proses ini seperti pemanfaatan air dari santan, ampas kelapa, dan blondo untuk pakan ternak.

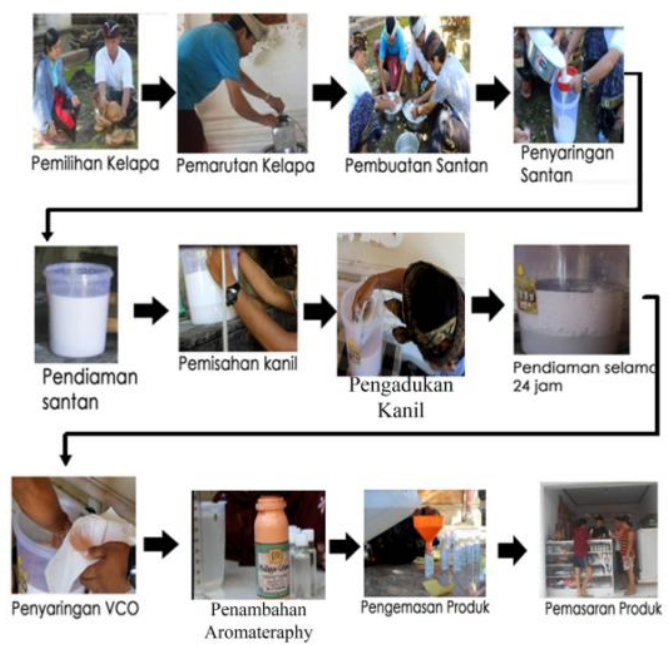

Gambar 2. Tahapan pembuatan VCO

\section{c) Pengemasan Produk VCO}

Pengemasan produk VCO dilakukan dengan memasukkan ke dalam botol-botol kecil dan diberikan label. Produk yang dihasilkan diberikan label VICONUT "Kelapa Pejati". Pada proses ini dihasilkan dua jenis produk yaitu VCO original dan aromaterapi jasmine. Pada proses ini dilatihkan tentang cara pencampuran minyak aromaterapi dengan VCO.

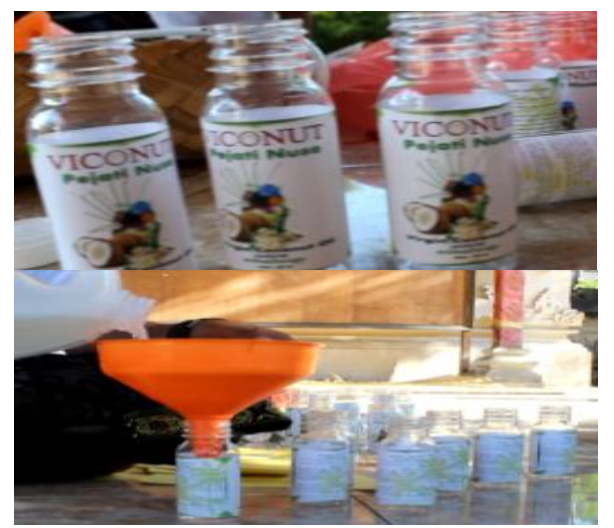

Gambar 3. Pengemasan produk 


\section{d) Pemasaran}

Setelah diperoleh produk, peserta diajarkan tentang cara mempromosikan dan memasarkannnya. Pada proses ini disepakati pemasaran dilakukan pada warung-warung di areal pura, tempat wisata, pelabuhan-pelabuhan, restoran ataupun spa di daerah Nusa Penida, serta ikut serta dalam kegiatan pameranpameran.

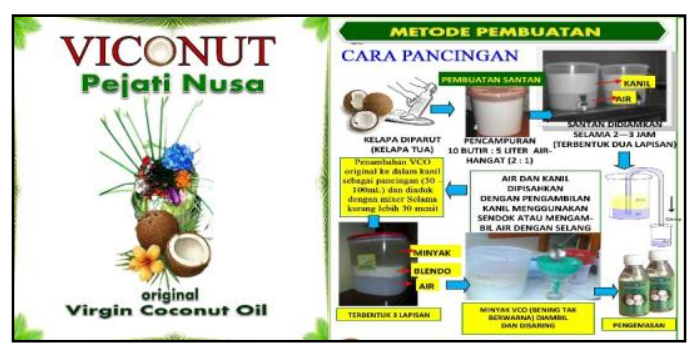

Gambar 4. Brosur

\section{e) Evaluasi}

Evaluasi dilakukan terhadap proses pelatihan dengan memberikan pre test dan post test. Hasil ini diolah dan dilampirkan dalam lampiran. Evaluasi lainnya yaitu mengenai kemampuan memasarkan produk VCO, sehingga produksi dapat berkelanjutan.

\section{HASIL DAN PEMBAHASAN Hasil Penyebaran Test}

1. Pre Test Informasi tentang VCO dan Pembuatan VCO (sebelum dilakukan sosialisasi dan proses pelatihan)

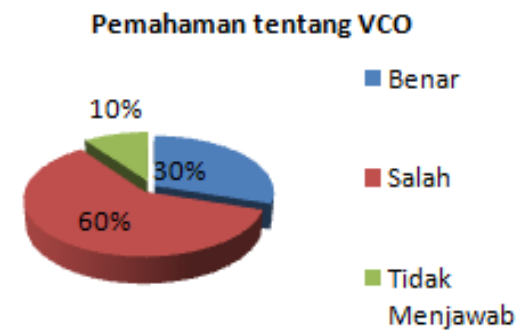

2. Post Test tentang VCO (setelah melakukan sosialisasi, pelatihan pembuatan VCO)

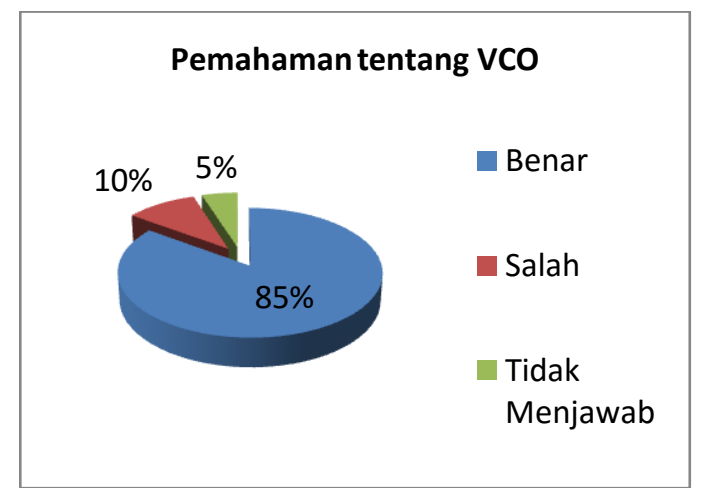

Dari hasil test yang sudah dilakukan sebelum dan sesudah pelatihan tingkat pemahaman tukang sapu berbeda. Sebelum pelatihan yang dilakukan oleh penulis tingkat pemahaman tukang sapu mengenai VCO, cara pembuatan VCO, dan Manfaat VCO masih sangat kurang, hal ini disebabkan karena tidak adanya informasi yang didapat oleh masyarakat Nusa Penida, Khususnya Tukang Sapu di areal Pura Penataran Dalem Ped. Setelah pelatihan yang sudah kami lakukan, tukang sapu tahu manfaat VCO, cara membuat VCO dan cara memasarkan VCO.

\section{Hasil Yang Dicapai}

Pada kegiatan yang sudah dilakukan yaitu pelatihan pembuatan VCO dari buah kelapa banten pejati, Tukang Sapu secara mandiri mampu membuat VCO dari kelapa banten pejati sesuai dengan kelompoknya (Setiap minggu dihasilkan 2-5 liter per orang) dan mampu untuk membuat serta mengemas produk VCO yang telah dibuat mejadi VCO aroma terapi jasmine dan original. Untuk meningkatkan pengelolaan kelapa dari pejati, tukang sapu membentuk sebuah kelompok pembuat VCO dengan nama kelompok "Nusa Kelapa". Kelompok Nusa Kelapa sudah mampu memasarkan produknya pada warung-warung di areal Pura Penataran Ped, tempat-tempat wisata, dan pelabuhan-pelabuhan di Nusa Penida. Selain tukang sapu memasarkan produknya, penulis membantu memasarkan produk VCO hasil pelatihan di Koperasi Mahasiswa, membuat stand pada expo dan pameran-pameran. Dengan hasil yang yang dicapai pendapatan para tukang sapu meningkat dari penghasilan sebelumnya hanya sebagai tukang sapu yaitu sebesar 
Rp. 1.300.000 serta manfaat dari produk VCO tidak hanya dirasakan oleh tukang sapu, masyarakat pengguna juga merasakan manfaat VCO pejati bagi kesehatan, hal ini dilihat dari testimony yang ada pada video kegiatan.

Hasil yang diperoleh dari kegiatan ini adalah sebagai berikut.

1. Tukang Sapu secara mandiri mampu membuat VCO dari kelapa pejati sesuai dengan kelompoknya (setiap minggu dihasilkan $2-5$ liter per orang)

2. Tukang Sapu mampu membuat dan mengemas produk menjadi VCO aroma terapi jasmine dan original.

3. Tukang sapu membentuk kelompok pembuat VCO dengan nama kelompok Nusa Kelapa dan memasarkan produk VCO pada pemedek (pengunjung pura).

4. Kelompok tukang sapu mampu memasarkan produknya pada warungwarung di areal Pura Dalem Ped, tempat-tempat wisata, dan pelabuhanpelabuhan di Nusa Penida.

5. Kelompok tukang sapu dapat memanfaatkan limbah dalam proses produksi untuk pakan ternak.

6. Kelompok tukang sapu memperoleh tambahan penghasilan dari produk VCO yang dibuat yaitu dari Rp. 100.000 sampai dengan Rp. 400.000 per minggunya.

7. Adanya antusiasme tukang sapu terhadap pelaksanaan program yang ditandai dengan absensi yang hadir.

8. Pemahaman kelompok tukang sapu tentang VCO dan pembuatannya mengalami peningkatan yang dapat dilihat dari hasil pre test dan post test.

9. Mahasiswa Tim PKMM membantu pemasaran produk VCO yang telah dilatihkan di Koperasi Mahasiswa, membuat stand pada expo kegiatan jurusan, festival, dan pameran-pameran

10. Masyarakat pengguna merasakan manfaat VCO pejati bagi kesehatan, hal ini dilihat dari testimony yang ada pada video kegiatan.

Adanya pemberdayaan sumber daya manusia (SDM) yang tepat, yaitu berupa pelaksanaan program pelatihan dan pengelolaan buah kelapa dari banten pejatipada tukang sapuyang potensial menciptakan trickle down effect (efek imbas). Efek imbas yang nampak adalah adanya produk hasil pelatihan yaitu VCO dan peningkatanpendapatan tukang sapu sebagai pemicu embrio perekonomian masyarakat petani kelapa..

Tabel 1. Presentase hasil dari target luaran

\begin{tabular}{|c|c|c|c|c|}
\hline No & Target Luaran & Presentase & Keterangan & Cara Pencapaian \\
\hline 1 & $\begin{array}{l}\text { Tukang Sapu } \\
\text { Pura } \\
\text { Penataran } \\
\text { Dalem Ped } \\
\text { mampu } \\
\text { membuat } \\
\text { produk VCO }\end{array}$ & $100 \%$ & 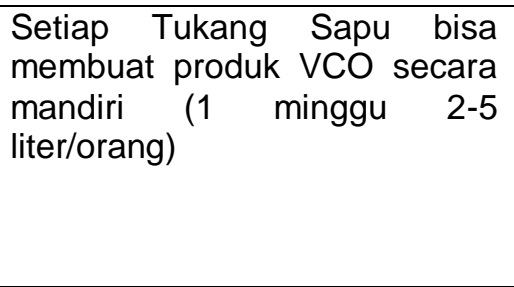 & $\begin{array}{l}\text { Melatihkan dan } \\
\text { melakukan } \\
\text { penyuluhan } \\
\text { pembuatan VCO }\end{array}$ \\
\hline 2 & $\begin{array}{l}\text { Tukang Sapu } \\
\text { di Pura } \\
\text { Penataran } \\
\text { Dalem Ped } \\
\text { mampu } \\
\text { membuat } \\
\text { diversifikasi } \\
\text { produk VCO } \\
\text { serta mampu } \\
\text { memasarkanny } \\
\text { a }\end{array}$ & $100 \%$ & $\begin{array}{l}\text { Tukang Sapu mampu membuat } \\
\text { diversifikasi produk VCO } \\
\text { original dan aromateraphy } \\
\text { serta mampu melakukan } \\
\text { pemasaran produk VCO } \\
\text { dengan cara : } \\
\text { 1. Menitipkan di warung } \\
\text { pada areal pura } \\
\text { 2. Tempat penyebrangan } \\
\text { (pelabuhan) } \\
\text { 3. Koperasi Mahasiswa } \\
\text { (Kopma Citra Dana } \\
\text { Undiksha) Stand pada } \\
\text { 4. Membuat Stand } \\
\text { acara festival } \\
\end{array}$ & $\begin{array}{l}\text { Melatihkan cara } \\
\text { pengemasan, } \\
\text { pembuatan } \\
\text { campuran } \\
\text { aromateraphy } \\
\text { dengan VCO (1 } \\
\text { liter: } 10 \mathrm{ml} \\
\text { aromateraphy) } \\
\text { dan memaparkan } \\
\text { cara pemasaran } \\
\text { dan } \\
\text { pengembangan } \\
\text { kewirausahaan. }\end{array}$ \\
\hline
\end{tabular}




\begin{tabular}{|c|c|c|c|c|c|}
\hline 3 & $\begin{array}{l}\text { Terdapat } \\
\text { kelompok kerja } \\
\text { sebagai wujud } \\
\text { pemberdayaan } \\
\text { dalam } \\
\text { mengolah } \\
\text { limbah kelapa } \\
\text { dari banten } \\
\text { peiati }\end{array}$ & $100 \%$ & $\begin{array}{l}\text { Terbentuk kelompok } \\
\text { dengan nama " } \\
\text { KELAPA" }\end{array}$ & $\begin{array}{r}\text { kerja } \\
\text { NUSA }\end{array}$ & $\begin{array}{l}\text { Membuat } \\
\text { kelompok dan } \\
\text { penjadwalan } \\
\text { pembuatan vco, } \\
\text { dan struktur } \\
\text { pengelolaan data } \\
\text { kelompok } \\
\text { (terlampir). }\end{array}$ \\
\hline & $\begin{array}{l}\text { laksantase } \\
\text { t Luaran }\end{array}$ & & $100 \%$ & & \\
\hline
\end{tabular}

\section{Potensi Keberlanjutan} adalah :

Potensi hasil dari kegiatan PKMM ini

1. Produk VCO dari limbah kelapa pejati menjadi produk komersial, karena VCO secara ilmiah bermanfaat untuk kesehatan. Selain itu produk VICONUT Kelapa Pejati dapat menjadi produk oleh-oleh dari Nusa Penida yang dipasarkan di kawasan strategis di Nusa Penida. Terciptanya produk VCO dari pejati yang dapat bermanfaat bagi kesehatan, apalagi kelapa yang digunakan merupakan kelapa yang sebelumnya telah didoakan dan dihaturkan sebagai bentuk persembahan.

2. Produk VICONUT aromaterapi jasmine menjadi produk unggulan yang bisa sebagai parfum dengan perawatan kulit dan spa, sehingga pengguna memperoleh keharuman dan manfaat VCO itu sendiri. Produk ini paling diminati oleh konsumen.

3. Sebagai bentuk motivasi dan menciptakan trickle down effect (efek imbas) tidak hanya kepada tukang sapu, tetapi juga kepada petani kelapa di Nusa Penida untuk mengolah kelapa menjadi produk yang lebih bernilai ekonomis sehingga mampu meningkatkan perekonomian petani

\section{KESIMPULAN}

Dari kegiatan yang sudah kami lakukan dapat kami simpulkan bahwa pelatihan pembuatan produk VCO dari banten pejati kepada tukang sapu Pura Penataran Dalem Ped sangat bermanfaat dilihat dari kebermanfaatan program yang bisa menghasilkan produk khas dari tukang sapu Penataran dalem Ped dan tepat sasaran terhadap masyarakat binaan yaitu dengan meningkatkan penghasilan dan memberikan keterampilan bagi tukang sapu. Sehingga tukang sapu di Pura Dalem Ped terberdayakan serta program ini berkelanjutan yaitu pengembangan produk agar tetap bisa dilakukan dan berkesinambungan.

Dengan adanya pelatihan ini kami harapkan adanya dukungan dari pihak pemerintah daerah sehingga dalam proses pemasarannya nanti adanya ruang khusus untuk tukang sapu memasarkan hasil produk dari buah kelapa pejati sebagai produk khas Nusa Penida

\section{DAFTAR PUSTAKA}

Bambang., S., dan Surip., P. 2006. Membuat VCO Berkualitas Tinggi. Jakarta : Penebar Swadaya.

Hadibroto, C, Srikandi W, 2006, Diet VCO, Gramedia Pustaka Utama, Jakarta.

Iskandar, 2006, Resume Seminar Kesehatan: Menguak Khasiat Dibalik Kejernihan VCO. Bulletin Dharmesti Niramaya Edisi 1/I/2006.(ISSN 1978-046x).

Raras., S.R., Pujiati., Utami., S. 2016. Pelatihan Pembuatan VCO Secara Fermentasi di Desa Belotan Bendo Magetan. Jurnal Terapan Abdimas. Vol 1 No.1.

Wibowo, S. 2006, "Manfaat Virgin Coconut Oil untuk Kesehatan", Prosiding Konferensi Nasional Kelapa VI.

Widiayanti, R., A. 2015. Pemanfaatan Kelapa Menjadi VCO sebagai Antibiotik. Prosiding Seminar Nasional. 